\title{
ИЗМЕНЕНИЕ ФУНКЦИЙ ПОЛИЦИИ/МИЛИЦИИ ПО СОДЕЙСТВИЮ СУДЕБНОМУ И ВОЕННОМУ ВЕДОМСТВАМ В РОССИИ ПЕРВОЙ ТРЕТИ ХХ ВЕКА: ИСТОРИКО-ПРАВОВОЙ АНАЛИЗ
}

\author{
С. Н. Токарева
}

Курский государственный университет

Поступила в редакцию 3 сентября 2020 г.

\begin{abstract}
Аннотация: с конца прошлого века остается актуальнылм вопрос исследования фбункиионирования дореволюиионной полиции, милииии Вреленного правительства, а также первых лет становления советской милииии. Процесс этот актуализировался 100-летним юбилеем организации советской рабоче-крестьянской милииии в 2017 г. и 300-летиел создания российской полиции в 2018 г. Ученье расслатривали разные аспекты данныц институтов нередко изолированно, в последнее же вреля ряд работ обобщают эти три периода. Тел более интересно, насколько был отвергнут или заилствован опьт, в частности правовой, при организации новых структур. В связи с этил в представленной статье автор анализирует норлативные правовые акты дореволюиионной России, Вреленного правительства и советской власти в части определения функиий органов правопорядка по содействию судебнолу и военнолу ведолствам. Видно, что часть норм права, даже в идентичной фборлулировке, сохранилась, но все-таки в советский период по этил направлениял полнолочия были сокращены (наприлер, относительно нотариальных действий).
\end{abstract}

Ключевые слова: полииия Российской илперии, народная (гражданская) милииия Вреленного правительства, советская рабоче-крестьянская милиция.

Abstract: from the end of the last century to the present days, the question of investigating the functioning of the pre-revolutionary police, the police of the Provisional Government, and the first years of the formation of the Soviet militia remains relevant. This process became urgent because of the 100th anniversary of the organization of the Soviet worker-peasant militia in 2017, and the 300-th anniversary of Russian police creation in 2018. Scientists have observed different aspects of these institutions separately. Nowadays, a number of scientists unite these three periods. It is all the more interesting to study, to what extent the experience has been rejected or borrowed, in particular legal in the organization of new structures. In this regard, in the present article the author analyzes the normative legal acts of pre-revolutionary Russia, the Provisional government and the Soviet government in terms of determining the functions of law enforcement agencies to assist the judicial and military departments. It can be seen that some of the rules of law have been preserved even in an identical formulation, but still in the Soviet period in these spheres the powers were reduced (for example, concerning notarial acts).

Key words: the Russian Empire police, people's (civil) militia of the Provisional government, Soviet workers 'and peasants' militia.

(C) Токарева C. Н., 2021 
В научной литературе вопросами исследования прошлого правоохранительных органов занимаются как историки, так и юристы. Помимо общих трудов по истории становления и деятельности полиции, в советское время выходили отдельные работы, посвященные в основном охране буржуазного правопорядка ${ }^{1}$. В 1990 -х гг. внимание к фонкционированию полиции актуализировалось, появились исследования и других направлений ее деятельности, например борьба с правонарушениями в сфрере общественной нравственности ${ }^{2}$. С началом нового тысячелетия объем публикаций по этой тематике значительно возрастает ${ }^{3}$. Однако авторы рассматривают преимущественно правоохранительные функции, практически без внимания остаются административно-исполнительные полномочия полиции по содействию другим учреждениям и ведомствам. А разграничение этих обязанностей и освобождение полиции от несвойственных ей функций было одной из важнейших задач реформы начала $\mathrm{XX}$ века. Функционированию народной милиции Временного правительства уделялось небольшое внимание в контексте обобщающих трудов по исследованию данного института. Деятельность советской рабоче-крестьянской милиции в первые годы ее становления рассматривалась более детально еще с 1980-х гг. ${ }^{4}$, однако также преимущественно в русле правоохранительных полномочий. Интересно не только описать эти обязанности, но и проследить динамику их изменения и закрепления в нормативных правовых актах царской России периода действия Временного правительства и первых лет становления советской власти. В последние десятилетия появились исследования и по функциям органов правопорядка в области судебного и военного ведомств: полиции Российской им-

${ }^{1}$ См.: Желудкова Т. И. Основные направления деятельности полиции дореволюционной России по охране феодального и буржуазного общественного порядка.

인 M., 1977.

${ }^{2}$ См.: Лысенко В. В. Правонарушения в сорере общественной нравственности и полиции России (история и современность). СПб., 1997.

${ }^{3}$ См.: Трошин Н. В. Административно-полицейские органы царской России в борьбе с экстремизмом и терроризмом во второй половине XIX - начале XX в. : дис. ... канд. ист. наук. Владимир, 2000 ; Рыжов Д. С. Борьба полиции России

162 с профессиональной преступностью (1866-1917 гг.) / под ред. А. В. Горожанина, А. Я. Малыгина. Самара, 2001 ; Савельева М. В. К вопросу о функциях полиции России начала XX века // История государства и права. 2003. № 1. С. 55-56 ; Седунов А. В. Российская полиция во второй половине XIX - начале XX в. : сфера компетенции, отношение к службе, реформирование // Там же. 2005. № 3. С. 4143 ; и др.

${ }^{4}$ См.: Власенков В. В. Деятельность милиции РСФСР по охране общественного порядка в период строительства социализма (1917-1936 гг.) : автореф. дис. ... канд. юрид. наук. М., 1981 ; Быстрюкова Н. И. Деятельность советской милиции по защите личных и имущественных прав граждан в период построения основ социализма (1917-1936 гг.) : авторефр. дис. ... канд. юрид. наук. М., 1981 ; Венисов А. В. Деятельность советской милиции по реализации решений местных органов власти в сфере охраны общественного порядка в период строительства социализма (1921-1936 гг.) : автореф. дис. ... канд. юрид. наук. М., 1987. 
перии, об обязанности отыскивать дезертиров во время Первой мировой войны, о взаимодействии полиции с судебными органами 5 .

В начале XX столетия в уездах не было отделений или представителей некоторых губернских управлений, в силу чего на полицейских возлагались самые разнообразные обязанности, которые в центре были распределены между различными присутственными местами. «Каждое губернское учреждение не могло иметь в уездах непременно своих исполнителей, так как пришлось бы тогда создать массу чиновников, большинству которых приходилось бы мало занятий, поэтому исполнение предписаний различных губернских учреждений возлагалось на полицию» 6 , которая в связи с этим и называлась «исполнительной».

Круг полномочий органов общей полиции по судебному ведомству включал:

1) прекращение всякого насилия, обид и самоуправства; производство дознаний и участие в предварительном следствии по уголовным делам;

2) представление суду обвиняемых и прикосновенных к делу лиц и взятие по его требованию под стражу;

3) вызов в суд, участие в приведении в исполнение судебных приговоров и определений;

4) опись, оценку, хранение и объявление о публичной продаже имений, а также продажу имущества;

5) понуждение поверенных к возвращению доверителям их доверенностей;

6) засвидетельствование доверенностей и исполнение других нотариальных обязанностей;

7) взыскание денег за приобретение крестьянами земли и на уплату нотариусу;

8) исследование о безвестном отсутствии лиц по делам бракоразводным;

${ }^{5}$ См.: Токарева C. Н. Административно-исполнительные обязанности полицейских управлений Российской империи начала ХХ столетия // Власть. 2013. № 1. С. 141-145 ; Ее же. Обязанности общей полиции Российской империи по судебному ведомству в начале XX века // Судебные реформы в контексте истории российской государственности : к 150-летию Судебных уставов 1864 г. (к 10-летию юридического фракультета Курского государственного университета) : материалы X Междунар. науч.-практ. конф. (г. Курск, 31 октября - 1 ноября 2014 г.). Курск, 2014. С. 58-61; Оськин М. В. Полиция Российской империи в годы Первой мировой войны : борьба с дезертирством // Современные проблемы права и управления : материалы III Междунар. науч. конф. : в 2 ч. / отв. ред. Н. Н. Антонова. Тула, 2013. С. 123-129; Красножон О. В. Журнал «Вестник полиции» о взаимодействии судебных органов и полиции Российской империи в начале XX века // Право и правосудие в России : истоки и современность : материалы Междунар. межвуз. науч.-практ. студ. конфр. : к 150-летию Судебной редрормы 1864 г. (г. Санкт-Петербург, 9 апреля 2014 г.). СПб., 2014. С. 60-62.

${ }^{6}$ Моллериус И. Руководство для полицейских чинов (пособие к изданию обязанностей полиции). СПб., 1911. Т. 1. С. 162. 
9) выдача членам семьи подсудимых чиновников удостоверений, что они не имеют никакого дохода и могут получать определенное по закону содержание от казны;

10) наблюдение за благоустройством в местах заключения и за исполнением постановлений о содержании и пересылке арестантов;

11) выдача свидетельств о родстве и свойстве заключенных лиц для допущения их к свиданию.

Обязанности военно-судебного и военно-морского судебного ведомств определялись специальными законамиㄱ.

Кроме того, в начале XX в. полиция была обязана составлять общие списки присяжных заседателей и тех, кто будет участвовать в очередном деле 8 . На практике часто отмечалось предоставление неверных сведений о лицах, подлежащих призыву к исполнению этих обязанностей, и медлительность чинов по вручению повесток, что приводило к таким случаям, когда не могли состояться сессии окружного суда ${ }^{9}$. А конвойные фонкции полиции негативно сказывались на несении наружной службы нижних чинов, которые отрывались от основного своего занятия.

Ранее полицейские служащие могли выполнять еще ряд нотариальных обязанностей по засвидетельствованию верности копий, подлинности подписей и нахождения лиц в живых ${ }^{10}$.

Более всего исполнительных действий по указанию судебного ведомства приходилось на обеспечение полицейского надзора.

К началу XX в. в Российской империи существовало несколько видов полицейского надзора $\left.{ }^{11}: 1\right)$ подследственный, т. е. учреждаемый до рассмотрения дела судебными органами; 2) судебный, устанавливаемый по приговору суда, и 3) административный, назначаемый правительственной властью без его вмешательства ${ }^{12}$. Какой-либо другой вид - н надзора законом был запрещен, а каждый из вышеперечисленных имел свое специальное назначение. В зависимости от наложения конкретного надзора полицейские должны были следить за поведением лица, доставлять его по требованию судебных властей, контролировать его передвижение и связи и т. д. С лиц, находящихся под гласным надзором, бралась

${ }^{7}$ Свод законов об обязанностях полиции. СПб., 1909. Ст. 683.

8 Там же. Ст. 228.

9 Государственный архив Курской области (далее - ГАКО). Ф. 1. Оп. 1. Д. 10326. Л. 150.

${ }^{10}$ Устав полицейский. СПб., 1913. Ст. 257.

${ }^{11}$ См.: Токарева С. Н. Полицейский надзор в Российской империи // Вопросы истории. Ежемесячный журнал. 2009. № 6. С. 94-104 ; Ee же. Полицейские и поднадзорные : российское законодательство и практика полицейского надзора в Курской губернии (конец XIX - начало XX в.) // Новый исторический вестник. 2013. № 4 (38). С. 28-55.

12 См.: Полицейский надзор : руководство по осуществлению подследственного, судебного и административного надзоров / сост. П. М. Люкевич. Ломжа, 1913. $\S 18-19$. 
подписка о невыезде за пределы губернии. Полицейские вели специальные ведомости о различных группах поднадзорных ${ }^{13}$.

Среди дореволюционных изданий, которые можно использовать в качестве источника исследования, можно встретить описание судебной полиции, руководства о порядке действий при вручении повесток, пересылке арестантов, исполнению судебных решений ${ }^{14}$.

Отметим, что с конца XIX в. по действовавшим уголовно-процессуальным нормам Российской империи полиция осуществляла ряд судебно-следственных мероприятий и фрункций прокуратуры ${ }^{15}$.

По делам военного ведомства в начале XX столетия деятельность общей полиции включала:

1) содействие и надзор за порядком в препровождении полков, наблюдение за выполнением для них натуральных повинностей;

2) обязанности по учету и призыву на действительную службу нижних чинов запаса армии и флота; выдача свидетельств и удостоверений и исполнение других обязанностей, изложенных в Уставе о воинской повинности;

3) извещение вдов нижних чинов о смерти мужей;

4) высылка нижних чинов, пропустивших срок прибытия к местам их служения ${ }^{16}$.

Департамент полиции 8 сентября 1907 г. разослал циркуляр губернаторам, где указал, что по соглашению с военным министром в целях ограждения войск гвардии и 1-го железнодорожного батальона от возможности проникновения в их среду политически неблагонадежных новобранцев устанавливалось, чтобы лица призывного возраста, намеченные уездными по воинской повинностями присутствиями к зачислению в указанные войсковые части поступали туда лишь после предварительного засвидетельствования их благонадежности местной жандармской и наружной полицией. После завершения работы местных призывных учреждений от уездных воинских начальников губернаторам должны были поступать именные списки новобранцев, признанных годными к поступлению в войска гвардии и в 1-й железнодорожный батальон для

${ }^{13}$ Государственный архив Орловской области (далее - ГАОО). Ф. 580. Оп. 1. Д. 4956. Л. 1-340.

${ }^{14}$ См.: Рейгардт Н. В. Судебная полиция. Казань, 1900 ; Памятка урядника и стражника : порядок вручения повесток должностных лиц общих и мировых судебных установлений / сост. И. С. Жолткевич. Юрьев, 1908 ; Сборник узаконений, циркулярных распоряжений и разъяснений по тюремно-арестантской и арестантско-пересыльной части, относящихся к ведению полиции / сост. Н. Н. Соловьев. Орел, 1911 ; Руководство для судебных приставов, чинов полиции и взыскателей по исполнению судебных решений / сост. М. Н. Преображенский. 2-е изд., испр. и доп. СПб., 1911.

${ }^{15}$ См.: Игнатьева K. С. Деятельность органов исполнительной полиции Российской империи в 1862-1905 гг. по противодействию и профилактике преступлений // Научные тенденции юриспруденции : материалы IX Междунар. науч. конф. (г. Санкт-Петербург, 20 ноября 2017 г.). СПб., 2017. С. 14-17.

${ }^{16}$ Свод законов об обязанностях полиции. СПб., 1909. Ст. 684. 


\section{Вестник ВГУ. Серия: Право}

выяснения благонадежности этих лиц в политическом отношении. По мере поступления этих списков они сообщались начальнику губернского жандармского управления и охранного отделения и наружной полиции для незамедлительного и тщательного наведения справок. В известность ставились уездные воинские начальники, чтобы эти сведения были у них до дня, назначенного для явки новобранцев из домашнего отпуска ${ }^{17}$.

В начале прошлого века чины полиции следили за лицами призывного возраста ${ }^{18}$, содействовали призыву новобранцев и контролировали поведение односельчан. Они должны были также оказывать содействие при мобилизации чинов запаса (вручали призывные карты, расследовали случаи неявки, следили за сбором в пункте назначения и т. д.) ${ }^{19}$.

Урядники и стражники должны были знать количество чинов запаса армии и фрлота своего участка и их место нахождения. В случае призыва чинов запаса объявляли, когда и куда они должны были явиться, какова их ответственность, что они могут взять с собой, выявлять причины неявки, арестовывать уклонявшихся от призыва, высылать подводы для призывников, следить за отведением квартир для проходящих команд и т. п. ${ }^{20}$

Во время Русско-японской и Первой мировой войн на начальников местной полиции возлагалась обязанность сообщать семьям о судьбе призванных, об их смерти или нахождении в плену ${ }^{21}$.

Полицейские разыскивали самовольно отлучившихся и не явившихся по месту назначения нижних военных чинов, особенно во время Первой мировой войны ${ }^{22}$.

При прохождении воинских команд канцелярия сообщала о времени, пункте назначения и другие сведения, чтобы полицейские могли предпринять все необходимые мероприятия (например, закрыть винные магазины $)^{23}$.

В этот период также издавались специальные методические пособия для пояснения действий полиции при производстве мобилизаций, воинской и военно-конской повинностям ${ }^{24}$.

${ }^{17}$ Центральный исторический архив г. Москвы. Ф. 46. Оп. 14. Д. 99. Л. 2-2 об.

${ }^{18}$ ГАКО. Ф. 310. Оп. 1. Д. 988. Л. 12-12 об. ; ГАОО. Ф. 580. Оп. 1. Д. 4319. Л. $1-105$.

$166{ }^{19}$ См.: Практическое руководство для гг. Исправников, Становых Приставов, Урядников, Стражников полицейской стражи и чинов полиции вообще при изучении полицейской службы в вопросах и ответах / сост. И. А. Смирнов. Вильна, 1913. C. $48-50$.

${ }^{20}$ См.: Там же.

${ }^{21}$ ГАКО. Ф. 1. Оп. 1. Д. 7455. Л. 87, 97, 112.

${ }^{22}$ Там же. Ф. 33. Оп. 2. Д. 16914. Л. 1-4 об.

${ }^{23}$ Там же. Ф. 1. Оп. 1. Д. 7572. Л. 3, 11, 13, 18, 20.

${ }^{24}$ См.: Руководство по производству пробных мобилизаций для сельских властей и чинов полиции. СПб., $1900 ;$ Корде М. П. Краткое руководство по воинской и военно-конской повинности для обучающихся в Ставропольской школе полицейских урядников. Ставрополь, 1900 ; Полное руководство и справочная книга для волостных правлений и младших чинов полиции по воинской и военно-конской повинностям, со всеми правительственными разъяснениями и распоряжениями 
При подготовке реформы, собрав сведения по законодательству и практике полицейских учреждений России и зарубежных стран, была сорормулирована главная задача - пересмотр функций полиции с целью освобождения от несущественных обязанностей, не отвечающих прямому назначению или относящихся к другим ведомствам и общественному самоуправлению.

Однако полностью провести редормирование полиции не удалось в силу событий февраля 1917 г. После буржуазной революции милиция перестала быть правительственным органом и соответственно представлять интересы его учреждений. Но, несмотря на ее переориентацию на муниципалитеты, по традиции дореволюционного периода за ней закрепили ряд обязанностей по другим ведомствам. К предметам ведения милиции по делам судебного ведомства относились ${ }^{25}$ :

1) производство дознаний и участие в предварительном следствии по уголовным делам на основании законов уголовного судопроизводства;

2) участие по делам публичного сообщения в качестве обвинителей в указанных законом случаях;

3) представление суду обвиняемых и других лиц, вызываемых по требованию суда, а также взятие их под стражу в случаях принятия соответствующего постановления;

4) вызовы к явке в суд для ответов, выслушивания решения и т. п., участие в приведении в исполнение судебных приговоров и определений, а также другие действия, предусмотренные в судопроизводственных законах;

5) обязанности по наблюдению за пересылкой арестантов, указанные в уставе о содержащихся под стражей;

6) хранение вещественных доказательств.

Как видно, список значительно сократился по сравнению с дореволющионным (например, исключены нотариальные действия), но новым пунктом являлось участие представителей гражданской милиции в определенных случаях в качестве обвинителей.

По делам военного ведомства милиция должна была заниматься ${ }^{26}$ :

1) обязанностями по учету и призыву на действительную службу чинов армии и фрлота;

(с прил. бланков) / сост. В. И. Марков и Д. Дубенский. 2-е изд., испр. и доп. СПб., 1902 ; Сборник (руководство) для учетных учреждений, как-то: городских полицейских управлений, становых и городских участковых приставов, полицейских надзирателей и волостных (гминных) правлений по ведению учета нижним чинам запаса и ратникам ополчения... / сост. Прокофьев и Лапшев. Казань, 1908 ; Руководство для призыва нижних чинов запаса армии и фрлота на действительную службу : с разъяснением для воинских присутствий, полицейских управлений, городских и земских управ и волостных правлений / сост. А. П. Федоров. Неофиц. изд. СПб., 1909.

${ }_{25}$ См.: Дурденевский В. Н. Новый закон о милиции (врем. полож. 17 апр. 1917 г.). М., 1917. С. 26.

${ }^{26}$ См.: Там же. 
2) извещением семейств воинских чинов о смерти последних, по установленным правилам;

3) сообщение военным властям сведений о проживающих в данной местности воинских чинах, просрочивших отпуск.

Данный перечень обязанностей практически идентичен дореволющионному, однако исключен пункт о содействии органов правопорядка при передвижении полков.

После Октября 1917 г. в первых советских нормативных правовых актах выделяется отдельная функциональная группа - содействие деятельности судебных органов ${ }^{27}$, а именно:

1) выполнение поручений судебных и следственных органов по задержанию и доставке в суд или для допроса обвиняемых, задержание подозреваемых в преступлениях и препровождение их в местные народные суды или следственные комиссии;

2) предоставление суду обвиняемых и других лиц, вызванных по требованию суда, а также взятие под стражу в случаях последующего соответствующего постановления;

3) вызовы к явке в суд и привод указанных судом или следственной комиссией лиц;

4) приведение в исполнение судебных приговоров;

5) вручение судебных повесток в тех случаях, если для этого не существовало особых лиц.

В данном списке уже не говорится об участии милиционеров в дознании, участии в качестве обвинителя, пересылке и хранении доказательств. Но, помимо традиционного предоставления лиц в суд и вручения повесток, возвращается исполнение судебных приговоров.

В период «военного коммунизма» в круг деятельности милиции входило оказание помощи вооруженным силам. Например, воспрещалось вывозить с территории губернии необходимые для фрронта материалы, продовольствие, фрураж, транспорт, у населения изымались необходимые предметы для армии, жители привлекались к трудовой повинности.

Это далеко не все дополнительные обязанности милиции, с ее помощью решались экономические задачи государства. Современник отмечал, что половина всего объема проводимой милицией работы не относилась

168 непосредственно к охране общественного порядка, борьбе с преступностью и обеспечению общественной безопасности. В 1920-е гг. некоторые полномочия также закреплялись за советской рабоче-крестьянской милицией (исполнение решений судов по определенной категории дел, некоторые нотариальные действия). Для их правильной реализации были опубликованы соответствующие инструкции ${ }^{28}$.

${ }^{27}$ Инструкция 1918 г. // СУ РСФСР. 1918. № 75. Ст. 813. П. 2-6 ст. 28.

${ }^{28}$ Инструкция о порядке исполнения органами милиции решений народных судов и земельных комиссий по гражданским делам. Бобров, [1924] ; Инструктивная сводка главнейших постановлений и правил для руководства исполняющим нотариальные действия народным судьям и райисполкомам, органам рабоче-крестьянской милиции и сельсоветам. Винница, 1924 ; Производство взысканий по 
Таким образом, за небольшой период первой трети XX столетия на фоне смены государственного устройства происходила тенденция выделения специфических для органов правопорядка функций и сокращения несвойственных для них полномочий. До наших дней прошла эволюция компетенций аналогичных подразделений, часть из них исполняется уже специализированными органами (прокуратурой, службой судебных приставов, нотариусами, военно-призывными комиссиями).

судебным решениям и постановления административных органов : руководство для судебных исполнителей, органов милиции, ВИКов, касс соц. страхования, фринагентов и др. Н. Новгород, 1925 ; Исполнение судебных решений, приговоров и определений судов и бесспорных взысканий : справ. книжка-комментарий для нар. судов, судеб. исполнителей, органов милиции и волисполкомов / сост. В. И. Лучанинов ; под ред. и вступ. слово Ф. И. Вольфсона. М., 1925 ; Инструкция судебным исполнителям : обязательна для органов волисполкома и милиции. 2-е изд., перераб. и доп. Л., 1925 ; и др.

Курский государственный универсиmem

Токарева С. Н., кандидат исторических наук, доцент каббедрь теории и истории государства и права

E-mail: tokareva_sn@mail.ru
Kursk State University

Tokareva S. N., Candidate of Historical Sciences, Associate Professor of the Theory and History of State and Law Department E-mail: tokareva_sn@mail.ru 